\title{
Entrepreneurship: Concepts, Theory and Perspective. Introduction
}

\author{
Álvaro Cuervo ${ }^{1}$, Domingo Ribeiro² y Salvador Roig ${ }^{2}$ \\ ${ }^{1}$ Universidad Complutense de Madrid \\ ${ }^{2}$ Universitat de València
}

The creation of a country's wealth and dynamism depends upon the competitiveness of its firms and this, in turn, relies fundamentally on the capabilities of its entrepreneurs and managers.

The essence of the modern firm lies in the specialization of functions. "The businessmen" that manage economic activity are, in the strictest sense, both managers and entrepreneurs, the latter in a double sense: the individual businessman (independent) and the "corporate entrepreneur" who, without participating significantly in terms of capital, controls the firm.

Studying offers of business capabilities requires the differentiation between the functions of entrepreneur, manager and capitalist, although in many cases, the same person may perform all three (table 1).

The individual entrepreneur detects or creates business opportunities that he or she then exploits through small and medium-sized firms, normally participating in funding the capital for that firm, carries out the role of arbitrator or simply "sells the idea" of the business project. The "corporate entrepreneur" or the chief executive of large firms must also be considered. This figure is no longer limited to efficiently managing the firm's assets and coordinating and controlling its activities; in the current climate, he or she must anticipate, articulate and manage change. In other words, they must reinvent the firm on a daily basis, creating new enterprise (spin-offs) and develop company networks. When discussing the figure of the corporate businessman, one must also consider the key shareholders that take an active part in the firm, along with managers that share in making up the firm's basic competences. 
Table 1. Entrepreneurs, managers and capitalists

\begin{tabular}{|c|c|c|c|}
\hline & ENTREPRENEUR & CAPITALIST & MANAGER \\
\hline $\begin{array}{l}\text { CHARACTERIZED } \\
\text { BY }\end{array}$ & $\begin{array}{l}\text { Discovers and exploits } \\
\text { opportunities } \\
\text { A creator who initiates } \\
\text { and motivates the process } \\
\text { of change }\end{array}$ & $\begin{array}{l}\text { Capital owner: } \\
\text { shareholders } \\
\text { Controlling share- } \\
\text { holder } \\
\text { Passive share- } \\
\text { holder }\end{array}$ & $\begin{array}{c}\text { Administrates and } \\
\text { manages resources } \\
\text { An administrator }\end{array}$ \\
\hline BEHAVIOUR & $\begin{array}{l}\text { Accepts risks } \\
\text { Uses intuition, is alert, } \\
\text { explores new business } \\
\text { Leadership, initiates } \\
\text { new ways of acting } \\
\text { Identifies business op- } \\
\text { portunities } \\
\text { Creation of new Enter- } \\
\text { prise }\end{array}$ & $\begin{array}{l}\text { Aversion to risk- } \\
\text { taking } \\
\text { Assesses alterna- } \\
\text { tives } \\
\\
\text { Choice of venture } \\
\text { assets }\end{array}$ & $\begin{array}{l}\text { Aversion to risk- } \\
\text { taking } \\
\text { "Rational" deci- } \\
\text { sion-maker. Explotes } \\
\text { business } \\
\text { Creates and main- } \\
\text { tains competitive ad- } \\
\text { vantage } \\
\text { Creates trust to en- } \\
\text { hance cooperation } \\
\text { Supervision of the } \\
\text { administrative process }\end{array}$ \\
\hline
\end{tabular}

However, the manager's function is first and foremost to supervise the process of combining resources, and efficiently manage the firm's business portfolio. They have a key function when, as is normally the case, firms do not operate efficiently (Leibenstein, 1979), and instead are a long way short of their production boundaries. A second but fundamental task of the manager is to build up a reputation and an atmosphere of trust that transforms a conflictive system (individuals with conflicting objectives) into a system of cooperation. Managers should create a climate of trust so that employees will not tend towards opportunist behaviour, even when it suits their short-term interests, as well as achieving a greater degree of efficiency by reducing supervision and agency costs.

Finally, the capitalist is the provider of the firm's funds, either in the form of a passive shareholder (in the case of small shareholders or institutional investors) or as a majority shareholder or active shareholder who, in many small and mediumsized firms, assumes both the entrepreneurial and managerial functions. 


\section{About entrepreneurship}

The entrepreneurial function implies the discovery, assessment and exploitation of opportunities, in other words, new products, services or production processes; new strategies and organizational forms and new markets for products and inputs that did not previously exist (Shane and Venkataraman, 2000). The entrepreneurial opportunity is an unexpected and as yet unvalued economic opportunity.

Entrepreneurial opportunities exist because different agents have differing ideas on the relative value of resources or when resources are turned from inputs into outputs. The theory of the entrpreneur focuses on the heterogeneity of beliefs about the value of resources (Alvarez and Busenitz, 2001: 756).

Entrepreneurship -the entrepreneurial function- can be conceptualized as the discovery of opportunities and the subsequent creation of new economic activity, often via the creation of a new organization (Reynolds, 2005).

Due to the fact that there is no market for "opportunities", the entrepreneur must exploit them, meaning that he or she must develop his or her capabilities to obtain resources, as well as organize and exploit opportunities. The downside to the market of "ideas" or "opportunities" lies in the difficulty involved in protecting ownership rights of ideas that are not associated with patents or copyrights of the different expectations held by entrepreneurs and investors on the economic value of ideas and business opportunities, and of the entrepreneur's need to withhold information that may affect the value of the project.

Entrepreneurship is often discussed under the title of the entrepreneurial factor, the entrepreneurial function, entrepreneurial initiative, and entrepreneurial behaviour and is even referred to as the entrepreneurial "spirit. The entrepreneurial factor is understood to be a new factor in production that is different to the classic ideas of earth, work and capital, which must be explained via remuneration through income for the entrepreneur along with the shortage of people with entrepreneurial capabilities. Its consideration as an entrepreneurial function refers to the discovery and exploitation of opportunities or to the creation of enterprise. Entrepreneurial behaviour is seen as behaviour that manages to combine innovation, risk-taking and proactiveness (Miller, 1983). In other words, it combines the classic theories of Schumpeter's innovative entrepreneur $(1934,1942)$, the risk-taking entrepreneur that occupies a position of uncertainty as proposed by Knight (1921), and the entrepreneur with initiative and imagination who creates new opportunities. Reference to entrepreneurial initiative underlines the reasons for correctly anticipating market imperfections or the capacity to innovate in order to create a "new combination". Entrepreneurial initiative covers the concepts of creation, risk-taking, renewal or innovation inside or outside an existing organization. Lastly, the entrepreneurial spirit emphasizes exploration, search and innovation, as opposed to the exploitation of business opportunities pertaining to managers. 
All this explains why entrepreneurship is described in different ways. The business process includes the identification and assessment of opportunities, the decision to exploit them oneself or sell them, efforts to obtain resources and the development of the strategy and organization of the new business project (Eckhardt and Shane, 2003). Entrepreneurship is "a process by which individuals -either on their own or within organizations- pursue opportunities" (Stevenson and Jarillo, 1990: 23). It has recently been claimed that if the managers and businessmen of many of our firms were to adopt entrepreneurial behaviour when developing their strategies, firms would be facing a much brighter future than current perceptions suggest (Lee and Peterson, 2000).

The entrepreneur's central activity is that of business creation, which can be studied at an individual and/or group level -analyzing psychological aspects and social variables of education, background or the family- either at an environmental level using variables that enable business development, or by analyzing aspects of the economic, social and cultural environments.

The study of entrepreneurs as individuals analyzes the variables that explain their appearance, such as personal characteristics, the psychological profile (the need for achievement, the capacity to control, tolerance of ambiguity and a tendency to take risks) or non-psychological variables (education, experience, networks, the family, etc.).

Equally, socio-cultural and institutional focuses underline the role of exclusion and social change as motivators of the entrepreneurial function in minority or marginalized groups. Studies on environmental variables emphasize culture or shared values in society, institutions linked to the legal framework, variables of the economic environment (demand) and the financial one (venture capital and cost), along with the spatial environment (clusters and economies of agglomeration).

Therefore, there are three basic ideas that explain the appearance of entrepreneurial activity. The first focuses on the individual, in other words, entrepreneurial action is conceived as a human attribute, such as the willingness to face uncertainty (Kihlstrom and Laffont, 1979), accepting risks, the need for achievement (McClelland, 1961), which differentiate entrepreneurs from the rest of society. The second fundamental idea emphasizes economic, environmental factors that motivate and enable entrepreneurial activity, such as the dimension of markets, the dynamic of technological changes (Tushman and Anderson, 1986), the structure of the market -normative and demographic- (Acs and Audretsch, 1990) or merely the industrial dynamic. The third factor is linked to the functioning of institutions, culture and societal values. These approaches are not exclusive (Eckhardt and Shane, 2003: 2), given that entrepreneurial activity is also a human activity and does not spontaneously occur solely due to the economic environment or technological, normative or demographic changes. 
When referring to entrepreneurs, there is normally a differentiation between individual entrepreneurs or businessmen (independent) and corporate entrepreneurs or businessmen associated with the higher echelons of a firm's management. Different names have been used to describe the latter such as "corporate Entrepreneurship”, “corporate venturing”, “intrapreneurship”, “internal corporate entrepreneurship" and "strategic renewal".

Entrepreneurial management can be considered as being different to traditional ways of managing organizations. Many managers are looking to new ways of making their organizations more entrepreneurial in many aspects, from a general strategic orientation to reward schemes (Brown, Davidsson and Wiklund, 2001). Barringer and Bluedorn (1999) emphasized a positive relationship between the intensity of corporate entrepreneurship and the intensity of the search for opportunities, strategic adaptation and value creation. As pointed out by Hitt et al. (2001: 488) "firms need to be simultaneously entrepreneurial and strategic".

Entrepreneurship is an essential element for economic progress as it manifests its fundamental importance in different ways: a) by identifying, assessing and exploiting business opportunities; b) by creating new firms and/or renewing existing ones by making them more dynamic; and c) by driving the economy forward through innovation, competence, job creation- and by generally improving the wellbeing of society.

Entrepreneurship affects all organizations regardless of size, or age, whether they are considered a private or public body, and independently of their objectives. Its importance for the economy is reflected in its visible growth as a subject of interest for the economic press and in academic literature. For this reason, it is a matter of interest to academics, businessmen and governments the world over.

The study of entrepreneurship leads us to attempt to answer a series of questions such as: What happens when entrepreneurs act? Why do they act? and How do they act? (Stevenson and Jarillo, 1990). Why, when and how do opportunities for the creation of goods and services come into existence? Why, when and how do some people and not others discover and exploit these opportunities? And finally, why, when and how are different modes of action used to exploit entrepreneurial opportunities? (Shane and Venkataraman, 2000).

We have limited knowledge of the opinion of entrepreneurs, business opportunities, the people that pursue them, the skills used for organizing and exploiting opportunities and the most favourable environmental conditions for these activities. .Moreover, studies are carried out at different levels; individual, firm, sector and geographical space. There is no basic theory for carrying out this type of study, resulting in approximations based on casuistry, anecdotes or fragmented reasoning (Eckhardt and Shane, 2003: 12). The black box of entrepreneurial function is yet to be opened (Fiet, 2001). 
The problems involved in a study of "entrepreneurship” are linked to the need to delimit the field of study and rely on a conceptual structure that enables the explanation and prediction of empirical phenomena that are not explained by other fields of knowledge; it is necessary to generate a paradigm, to develop a set of testable hypotheses, to overcome the existing casuistry and description and look further into longitudinal and cross-sectional analysis.

Despite all this, a considerable body of literature has accumulated on the subject of entrepreneurship to the point where, just as has happened in other fields, a sizeable number of entrepreneurship-related studies have been published in journals in the areas of administration and management, while other journals that specifically specialize in topics related entrepreneurship have appeared. The role of the entrepreneur has been analyzed in special issues in journals such: Strategic Management Journal and Journal of Management (Audretsch et al., 2005), Academy of Management Journal and Journal of International Marketing (Coviello and Jones, 2004). Almost a hundred journals can be adjudged to have published work related to entrepreneurship (Entrepreneurship Division of the Academy of Management, in research carried out in the summer of 2006).

The differentiation of the field of entrepreneurship from other areas depends upon the object of the research, the methodologies and the problems researchers are attempting to resolve (Bruyat and Julien, 2000). Busenitz et al., (2003: 286) underline the importance of recognizing "entrepreneurship as a field of study within management”, a field of knowledge that upholds the development of entrepreneurship. It is on these fundamental ideas that we base our reflections.

The study and teaching of entrepreneurship and the role played by professors dedicated to teaching and research on this topic are of growing importance, as reflected by the boom in courses and chairships in entrepreneurship in the United Status in the last few years (Finkle, Kuratko and Goldsby, 2006). The University of Valencia has joined this trend through the creation of the first chairship of this kind in Spanish universities: the Bancaja Chair for Young Entrepreneurs, dedicated to the study, research and development of aspects related to entrepreneurship.

\section{About the book}

The book consists of 15 chapters grouped into three sections. These are: Concepts, Theory and Perspective. Each chapter contains a published article that has played a relevant role in the scientific consolidation of Entrepreneurship, which may be so in the future or which presents some complementary element to the vision of the field of Entrepreneurship. We are aware of the absence of some well-known, highly-regarded texts. This is due to the fact that, in the difficult task of reducing 
an original list of more than 100 references, we have opted for the complementarity of the contents, thus avoiding any superfluous inclusions. The final choice of articles inevitably reflects our own links with business management.

The first part of the book, Concepts, aims to provide a range of terminology and conceptual ideas, at the same time as giving an account of the historical evolution and theoretical location of the different approaches to Entrepreneurship. This first section consists of four chapters.

The first chapter, contributed by Professor Veciana, is the updated version of a study carried out in 1999. It presents, describes and classifies theories that have been used to give structure to and formalize the field of study. For such a classification, the author creates a matrix based on four theoretical approaches: economic, psychological, institutional and managerial - and three levels of analysis within entrepreneurship, micro, meso and macro. In the subsequent grid, twenty five theories on entrepreneurship are located. The comprehensive bibliography is an indication of the extensive and fruitful academic and research activity of one of Europe's pioneers in the study of entrepreneurship.

The second chapter contains the oldest of the texts that appear in this book, but it is one that has also had huge repercussions in the history of the field, in terms of citations. Carland et. al. present entrepreneurship as being independent from capitalists and from management, and discuss the contribution of entrepreneurship to small businesses and to the economy as a whole. The authors underline the importance of the difference between entrepreneurial firms and new or small firms. They propose a criterion for identifying entrepreneurial firms, which consist of complying with at least one of the four conditions that, according to Schumpeter (1934), reflect entrepreneurial behaviour: the introduction of new products, the introduction of new modes of production, the opening up of new markets or an industrial reorganization with sufficient conditions to classify a firm as being entrepreneurial.

The third chapter, provided by Sharma and Chrisman, addresses the problem of the differences that exist in the terminology used to describe entrepreneurship, with the idea of reducing the confusion that surrounds the field and reconciling differences between existing definitions. The authors provide a definition both for entrepreneurship and for the entrepreneur. For Sharma and Chrisman, entrepreneurship covers the occurrence of organizational creation or innovation that occurs inside or outside the existing organization, whilst entrepreneurs are individuals or groups of individuals that act independently, or as part of a corporate system, that create new organizations or instigate renewal or innovation within an existing one. The authors analyze Corporate Entrepreneurship and, following a discussion on internal and external firm creation, provide a classification of internal firm creation, with a particular focus on structural autonomy and the degree of the relationship with the lines of business of the firm that motivates such a creation. 
In the fourth chapter, which concludes the first section, Aldrich and Fiol, point out the high levels of risk undertaken by firms that are created in emerging sectors. The text looks at certain procedures that can be employed in order for a sector to obtain legitimacy at an institutional level. Several strategies are also presented that have been used by particular firms in newly emerging sectors.

The second section of the book, which includes chapters five to ten, deals with three important paradigms in the evolution of entrepreneurship and contributes two theoretical viewpoints that, despite having a more limited scope, have the advantage of strong links with other disciplines or bodies of knowledge.

Chapter five contains the work of Low and Macmillan, which appeared in 1988. The authors propose the definition of the field of entrepreneurship as "the creation of new enterprise" and from this standpoint, they suggest six requirements that research on entrepreneurship should comply with: purpose, theoretical perspective, focus, level of analysis, time frame and methodology. Having established these requirements, they assess previously published research in order to evaluate to what extent they comply and give guidelines for future research in the field.

In the sixth chapter, Stevenson and Jarillo begin by discussing the apparent conceptual conflict between entrepreneurship and corporate entrepreneurship. In order to surpass theoretical tradition that attempted to explain the causes of entrepreneurial behaviour, its economic and social outcomes or entrepreneurial activity in a way that can be considered too independent, they accept the concept of entrepreneurship as a process via which individuals -either on their own or within organizations- look for opportunities without taking into account the resources they have at their disposition at a given time. Using this definition, the subject may cease to be an individual and become an organization. From thereon in, they apply their conclusions to corporate entrepreneurship, laying down the characteristics of the entrepreneurial organization.

The seventh chapter corresponds to the study by Shane and Venkataraman, "The promise of entrepreneurship as a field of research". The authors consider the existence, nature and discovery of opportunities as the real core of entrepreneurship and provide some reasons as to why certain people recognize these opportunities while others do not. At the same time, they research ways of developing and making the most of opportunities according to the form they take. By considering opportunities to be the core of entrepreneurship, they are indicating a specific field of research and establish differences with the classical, psychological approach, the strategic approach and that of economic equilibrium.

The eighth chapter constitutes a look at cognitive theory applied to entrepreneurship. Therein, Krueger proposes a cognitive model, based on intentions, that processes the perception of opportunities and assesses their desirability and feasibility. The article constitutes a detailed discussion on the importance of a strategic orientation towards new opportunities, as well as its basic nature. Cognitive theory 
is currently the main link between entrepreneurship and the science of psychology.

In the ninth chapter, Alvarez and Busenitz propose a relationship between a resource-based theory and entrepreneurship. By doing so, they offer new perspectives that extend the boundaries of resource theory while using such theoretical trappings to address important questions concerning entrepreneurship. From the perspective of a resource-based theory, they assess "the recognition of opportunities and opportunity-seeking behaviour" as a resource, along with "the process of combining and organizing resources". The article also includes a discussion on cognition and business competence, the recognition of opportunities, strategic complementarity and causal ambiguity with regard to the ex post limitations to the act of competing.

In the tenth chapter, Gartner uses the six key recommendations for specifying research into entrepreneurship provided by Low and Macmillan (1988), (purpose, theoretical perspective, focus, level of analysis, time frame and methodology, in order to analyze the article written by Shane and Venkataraman (2000), "The promise of entrepreneurship as a field of research". In other words, the methodology proposed in chapter five is used to analyze the study in chapter seven, thus demonstrating the usefulness of the methodology proposed by Low and MacMillan and underlining the soundness of the ideas included in the study by Shane and Venkataraman. It is their recommendation that communities of academics should arise within the field of entrepreneurship that identify themselves with specific questions and research topics.

The third part of the book is made up of five chapters, of which the first three focus on presenting suggestions for future investigation in entrepreneurship, with the aim of achieving consolidation as a scientific field. This section also includes an international project on entrepreneurship and recommendations for analyzing and facilitating the publication of research on entrepreneurship.

In chapter eleven, Davidsson and Wiklund, basing their ideas on the results obtained by Low and MacMillan (1988), study the levels of analysis that have been identified in studies on entrepreneurship. They then go on to provide defined examples of progress for specific levels of analysis: for example, individual and team, firm, industry/ population, regional and national. The authors propose that progress in the future will depend on a closer relationship between the theories of entrepreneurship and levels of analysis.

Chapter twelve is a study created by a group of professors from the Entrepreneurship Division of the Academy of Management. They propose the existence of three areas that are central to research on entrepreneurship: opportunities, ways of organizing and putting into effect the exploitation of opportunities and the study of the environment. They suggest that the most fertile ground is to be found at the intersections of those areas and they locate both at the intersections and in the areas 
themselves, a sample of 97 articles published in the main academic journals for this topic. In addition, they use the same sample to assess the degree of consolidation of the scientific field of entrepreneurship, as well as its level of scientific legitimacy and the flow of exchange with other fields. The conclusions drawn from this assessment are not particularly encouraging and, although significant advances are recognized, it can be ascertained from this article that any real consolidation is still lacking in comparison with the enormous popularity and interest that the subject of entrepreneurship attracts today.

Chapter 13, written by Aldrich and Martinez, presents three tendencies observed in the last decade: a) a switch from the theoretical emphasis on the characteristics of entrepreneurs as individuals to the consequences of their actions, b) a deeper understanding of how entrepreneurs use knowledge, networks and resources to create businesses, and c) a more sophisticated taxonomy of the environmental forces at different levels of analysis (population, community and society) that affect entrepreneurship. The authors believe that progress has been made with regard to knowledge of the "process" of entrepreneurship, but that a better characterization of the "entrepreneurial context" is still needed, along with an analysis of a resource-based interaction of process and context. Together with a more sophisticated assessment of strategy and the environment, the authors suggest that progress can be made by creating theoretically derived hypotheses, adding longitudinal information and applying modern statistical techniques.

Chapter fourteen, provided by Morales and Roig, analyzes the influence of the main factors that appear in the relevant literature on the decision to start a new firm; identifying the perception of business opportunities, making use of the knowledge of other entrepreneurs and the perceptions held on the necessary skills as crucial elements of the process. They also analyze an aversion to risk-taking, especially when it affects the family's expectations for the future, as well as higher income and a higher level of academic studies as limiting factors to the likelihood of starting a new firm. The conclusions are drawn from the database published with the results of the GEM (Global Entrepreneurship Monitor), which contains information from 29 different countries.

Chapter fifteen contains the ideas developed by Ireland, Reutzel and Webb, editors of the Academy of Management Journal, on the evolution of research on entrepreneurship published in this prestigious journal, in clear competition with research in other areas of management. This study offers some expectations for research into entrepreneurship that the AMJ might publish in the future, at the same time as calling for greater attention to technical statistics, such as measurements of validation and the interpretation of facts and results. 


\section{The relevance of these articles to the field of entrepreneurship}

The selection of articles included herein are, without doubt due to personal choice and are the sole responsibility of the editors, though attention has been paid to impact factors and citation indices, mainly the ISI/JCR and EBSCO. The impact of the journals, the authors and the articles on academic activity can be identified through measuring how widely they are used, thanks to the number of times they are cited in subsequent studies. For some time now, total numbers of citations have been considered an important yardstick for gauging the quality of an article, the relevance of the author's work, and the status of the journal where the articles appeared (Garfield, 1972, 1979; Chandy and Williams, 1994; Jonson and Podsakoff, 1994; Knight, Hult, and Bashaw, 2000).

However, with regard to this field in particular, we have found two relevant biases; on the one hand, citation indexes have led to a surfeit of articles with a larger financial component, giving priority to those of an informative nature or to the detriment of those that are more theory-based. On the other hand, it is natural for older articles to have received more citations than recent publications and thus the influence of more up-to-date studies cannot be demonstrated by using citation counts, although there are a few exceptions, such as the case of Shane and Venkataraman (2000).

Articles published between 1945 and 2005, in journals appearing in the ISI under the categories of "business", "management" or "economics" were chosen. If they appeared before 1991, they had to have received at least five citations according to the database of the Social Science Citation Index (SSCI), which provided an initial sample of 2,564 articles. In turn, these articles contained 102,331 citations pertaining to a total 61,336 different documents.

Table 1 lists articles from the initial sample published in academic journals and placed in order of decreasing number of citations received according to the database of the Social Science Citation Index. These are all ISI articles cited in ISI journals. It is, in our opinion, an endogamous selection from an extremely limited sample and consequently is not representative of the population of documents that form the basis of research.

The fifty most frequently cited articles from the sample are shown, taken from the SSCI database between 1945 and 2005. In this listing, the time lapse between the publication of an article and the first citations can be clearly seen. Moreover, the older articles have had more exposure to new generations of authors and thus are more likely to receive a greater number of citations. This makes it appropriate to subdivide the citation according to when they were published. 
Table 1.50 Most frequently cited articles from the initial sample of the SSCI database.

\begin{tabular}{|c|c|c|}
\hline der & Citations & Article \\
\hline 1 & 274 & $\begin{array}{l}\text { Uzzi, B. 1997. Social structure and competition in interfirm } \\
\text { networks: the paradox of embeddedness. Administrative Sci- } \\
\text { ence Quarterly, } 42 \text { (1): } 35-67 \text { Mar. }\end{array}$ \\
\hline 2 & 225 & $\begin{array}{l}\text { Petersen, M.A. \& Rajan, R.G. 1994. The benefits of lend- } \\
\text { ing relationships - evidence from small business data. Journal } \\
\text { of Finance, } 49 \text { (1): 3-37 Mar. }\end{array}$ \\
\hline 3 & 209 & $\begin{array}{l}\text { Deshpande, R., Farley, J.U. \& Webster, F.E. 1993. Corpo- } \\
\text { rate culture, customer orientation, and innovativeness in japa- } \\
\text { nese firms - a quadrad analysis. Journal of Marketing, } 57 \text { (1): } \\
23-27 \text { Jan. }\end{array}$ \\
\hline 4 & 206 & $\begin{array}{l}\text { Evans, D.S. \& Jovanovic, B. 1989. An estimated model of } \\
\text { entrepreneurial choice under liquidity constraints. Journal of } \\
\text { Political Economy, } 97 \text { (4): 808-827 Aug. }\end{array}$ \\
\hline 5 & 185 & $\begin{array}{l}\text { Brickley, J.A. \& Dark, F.H. } 1987 \text {. The choice of organiza- } \\
\text { tional form - the case of franchising. Journal of Financial Eco- } \\
\text { nomics, } 18 \text { (2): } 401-420 \text { Jun. }\end{array}$ \\
\hline 6 & 165 & $\begin{array}{l}\text { King, R.G. \& Levine, R. 1993. Finance, entrepreneurship, } \\
\text { and growth - theory and evidence. Journal of Monetary Eco- } \\
\text { nomics, } 32 \text { (3): } 513-542 \text { Dec. }\end{array}$ \\
\hline 7 & 156 & $\begin{array}{l}\text { Treadway, A.B. 1969. Rational entrepreneurial behaviour } \\
\text { and demand for investment. Review of Economic Studies, } 36 \\
\text { (2): } 227-239 \text {. }\end{array}$ \\
\hline 8 & 155 & $\begin{array}{l}\text { Nee, V. 1992. Organizational dynamics of market transi- } \\
\text { tion - hybrid forms, property-rights, and mixed economy in } \\
\text { china. Administrative Science Quarterly, } 37 \text { (1): 1-27 Mar. }\end{array}$ \\
\hline 9 & 148 & $\begin{array}{l}\text { Miller, D. 1983. The correlates of entrepreneurship in } 3 \\
\text { types of firms. Management Science, } 29 \text { (7): } 770-791 \text {. }\end{array}$ \\
\hline 10 & 136 & $\begin{array}{l}\text { Miller, D. \& Friesen, P.H. 1982. Innovation in conservative } \\
\text { and entrepreneurial firms - } 2 \text { models of strategic momentum. } \\
\text { Strategic Management Journal, } 3 \text { (1): } 1-25 \text {. }\end{array}$ \\
\hline 11 & 135 & $\begin{array}{l}\text { Lafontaine, F. 1992. Agency theory and franchising - some } \\
\text { empirical results. Rand Journal of Economics, } 23 \text { (2): 263-283 } \\
\text { sum. }\end{array}$ \\
\hline 12 & 133 & $\begin{array}{l}\text { Eisenhardt, K.M. \& Schoonhoven, C.B. 1996. Resource- } \\
\text { based view of strategic alliance formation: strategic and social } \\
\text { effects in entrepreneurial firms. Organization Science, } 7 \text { (2): } \\
\text { 136-150 Mar-Apr. }\end{array}$ \\
\hline 13 & 124 & $\begin{array}{l}\text { Aghion, P. \& Bolton, P. 1992. An incomplete contracts ap- } \\
\text { proach to financial contracting. Review of Economic Studies, } \\
59 \text { (3): } 473-494 \text { jul. }\end{array}$ \\
\hline 14 & 123 & $\begin{array}{l}\text { Banerjee, A.V. \& Newman, A.F. 1993. Occupational choice } \\
\text { and the process of development. Journal of Political Econ- } \\
\text { omy, } 101 \text { (2): } 274-298 \text { Apr. }\end{array}$ \\
\hline 15 & 122 & $\begin{array}{l}\text { Shane, S.A. \& Venkataraman, S. } 2000 \text {. The promise of en- } \\
\text { trepreneurship as a field of research. Academy of Manage- } \\
\text { ment Review, } 25 \text { (1): } 217-226 \text { Jan. }\end{array}$ \\
\hline 16 & 116 & $\begin{array}{l}\text { Mintzberg, H. \& Waters, J.A. 1982. Tracking strategy in an } \\
\text { entrepreneurial firm. Academy of Management Journal, } 25 \\
\text { (3): 465-499. }\end{array}$ \\
\hline 17 & 115 & $\begin{array}{l}\text { Baumol, W.J. 1990. Entrepreneurship - productive, unpro- } \\
\text { ductive, and destructive. Journal of Political Economy, } 98 \text { (5): } \\
893-921 \text { part } 1 \text { Oct. }\end{array}$ \\
\hline
\end{tabular}




\begin{tabular}{|c|c|c|}
\hline 18 & 114 & $\begin{array}{l}\text { Gartner, W.B. 1985. A conceptual-framework for describ- } \\
\text { ing the phenomenon of new venture creation. Academy of } \\
\text { Management Review, } 10 \text { (4): 696-706. }\end{array}$ \\
\hline 19 & 114 & $\begin{array}{l}\text { Kihlstrom, R.E. \& Laffont, J.J. 1979. General equilibrium } \\
\text { entrepreneurial theory of firm formation based on risk aver- } \\
\text { sion. Journal of Political Economy, } 87 \text { (4): } 719-748 \text {. }\end{array}$ \\
\hline 20 & 112 & $\begin{array}{l}\text { Petersen, M.A. \& Rajan, R.G. } 1995 \text {. The effect of credit } \\
\text { market competition on lending relationships. Quarterly Journal } \\
\text { of Economics, } 110 \text { (2): } 407-443 \text { may. }\end{array}$ \\
\hline 21 & 110 & $\begin{array}{l}\text { Caves, R.E. \& Murphy, W.F. 1976. Franchising - firms, } \\
\text { markets, and intangible assets. Southern Economic Journal, } \\
42 \text { (4): } 572-586 \text {. }\end{array}$ \\
\hline 22 & 109 & $\begin{array}{l}\text { Blanchflower, D.G. \& Oswald, A.J. 1998. What makes an } \\
\text { entrepreneur? Journal of Labor Economics, } 16 \text { (1): 26-60 } \\
\text { Jan.. }\end{array}$ \\
\hline 23 & 108 & $\begin{array}{l}\text { Burgelman, R.A. 1983. Corporate entrepreneurship and } \\
\text { strategic management - insights from a process study. Man- } \\
\text { agement Science, } 29 \text { (12): 1349-1364. }\end{array}$ \\
\hline 24 & 101 & $\begin{array}{l}\text { Carland, J.W., Hoy F., Boulton, W.R., et al. 1984. Differen- } \\
\text { tiating entrepreneurs from small business owners - a concep- } \\
\text { tualization. Academy of Management Review, } 9 \text { (2): } 354-359 \text {. }\end{array}$ \\
\hline 25 & 101 & $\begin{array}{l}\text { Hart, O. \& Moore, J. 1994. A theory of debt based on the } \\
\text { inalienability of human-capital. Quarterly Journal of Econom- } \\
\text { ics, } 109 \text { (4): } 841-879 \text { Nov. }\end{array}$ \\
\hline 26 & 100 & $\begin{array}{l}\text { Brockhaus, R.H. 1980. Risk-taking propensity of entrepre- } \\
\text { neurs. Academy of Management Journal, } 23 \text { (3): 509-520. }\end{array}$ \\
\hline 27 & 99 & $\begin{array}{l}\text { Bates, T. } 1990 \text {. Entrepreneur human-capital inputs and } \\
\text { small business longevity. Review of Economics and Statistics, } \\
72 \text { (4): } 551-559 \text { Nov. }\end{array}$ \\
\hline 28 & 96 & $\begin{array}{l}\text { Holtzeakin, D., Joulfaian, D., \& Rosen, H.S. } 1994 \text {. Sticking } \\
\text { it out - entrepreneurial survival and liquidity constraints. Jour- } \\
\text { nal of Political Economy, } 102 \text { (1): } 53-75 \text { Feb. }\end{array}$ \\
\hline 29 & 94 & $\begin{array}{l}\text { Norton, S.W. 1988. An empirical look at franchising as an } \\
\text { organizational form. Journal of Business, } 61 \text { (2): 197-218 Apr. }\end{array}$ \\
\hline 30 & 91 & $\begin{array}{l}\text { Dewatripont, M. \& Maskin, E. } 1995 \text {. Credit and efficiency in } \\
\text { centralized and decentralized economies. Review of Eco- } \\
\text { nomic Studies, } 62 \text { (4): } 541-555 \text { oct. }\end{array}$ \\
\hline 31 & 89 & $\begin{array}{l}\text { Millson, M.R., Raj, S.P. \& Wilemon, D. 1992. A survey of } \\
\text { major approaches for accelerating new product development. } \\
\text { Journal of Product Innovation Management, } 9 \text { (1): 53-69 Mar }\end{array}$ \\
\hline 32 & 83 & $\begin{array}{l}\text { Stuart, T.E., Hoang, H. \& Hybels, R.C. 1999. Interorgani- } \\
\text { zational endorsements and the performance of entrepreneu- } \\
\text { rial ventures. Administrative Science Quarterly, } 44 \text { (2): 315- } \\
349 \text { Jun. }\end{array}$ \\
\hline 33 & 82 & $\begin{array}{l}\text { Fiol, C.M. 1994. Consensus, diversity, and learning in or- } \\
\text { ganizations. Organization Science, } 5 \text { (3): } 403-420 \text { Aug. }\end{array}$ \\
\hline 34 & 82 & $\begin{array}{l}\text { Gersick, C.J.G. 1994. Pacing strategic change - the case } \\
\text { of a new venture. Academy of Management Journal, } 37 \text { (1): } \\
9-45 \text { Feb. }\end{array}$ \\
\hline 35 & 82 & $\begin{array}{l}\text { Sandberg, W.R. \& Hofer, C.W. 1987. Improving new ven- } \\
\text { ture performance - the role of strategy, industry structure, and } \\
\text { the entrepreneur. Journal of Business Venturing, } 2 \text { (1): } 5-28 \\
\text { win. }\end{array}$ \\
\hline 36 & 82 & $\begin{array}{l}\text { Vandeven, A.H., Hudson, R. \& Schroeder, D.M. 1984. De- } \\
\text { signing new business startups - entrepreneurial, organiza- } \\
\text { tional, and ecological considerations. Journal of Management, }\end{array}$ \\
\hline
\end{tabular}




\begin{tabular}{|c|c|c|}
\hline & & 10 (1): 87-107. \\
\hline 37 & 77 & $\begin{array}{l}\text { Oviatt, B.M. \& McDougall, P.P. 1994. Toward a theory of } \\
\text { international new ventures. Journal of International Business } \\
\text { Studies, } 25 \text { (1): } 45-64 \text {. }\end{array}$ \\
\hline 38 & 75 & $\begin{array}{l}\text { Busenitz, L.W. \& Barney, J.B. 1997. Differences between } \\
\text { entrepreneurs and managers in large organizations: biases } \\
\text { and heuristics in strategic decision-making. Journal of Busi- } \\
\text { ness Venturing, } 12 \text { (1): 9-30 jan. }\end{array}$ \\
\hline 39 & 74 & $\begin{array}{l}\text { holtzeakin d, joulfaian d, rosen hs } 1994 \text {. entrepreneurial } \\
\text { decisions and liquidity constraints. rand journal of economics } \\
25 \text { (2): } 334-347 \text { sum. }\end{array}$ \\
\hline 40 & 73 & $\begin{array}{l}\text { Cooper, A.C., Woo, C.Y. \& Dunkelberg, W.C. 1988. Entre- } \\
\text { preneurs perceived chances for success. Journal of Business } \\
\text { Venturing, } 3 \text { (2): } 97-108 \text { spr. }\end{array}$ \\
\hline 41 & 72 & $\begin{array}{l}\text { Begley, T.M. \& Boyd, D.P. 1987. Psychological character- } \\
\text { istics associated with performance in entrepreneurial firms } \\
\text { and smaller businesses. Journal of Business Venturing, } 2 \text { (1): } \\
79-93 \text { win. }\end{array}$ \\
\hline 42 & 72 & $\begin{array}{l}\text { Peterson, R.A. \& Berger, D.G. 1971. Entrepreneurship in } \\
\text { organizations - evidence from popular music industry. Admin- } \\
\text { istrative Science Quarterly, } 16 \text { (1): } 97-107 \text {. }\end{array}$ \\
\hline 43 & 70 & $\begin{array}{l}\text { Jacobson, R. 1992. The austrian school of strategy. Acad- } \\
\text { emy of Management Review, } 17 \text { (4): } 782-807 \text { oct. }\end{array}$ \\
\hline 44 & 68 & $\begin{array}{l}\text { Stevenson, H.H. \& Jarillo, J.C. 1990. A paradigm of entre- } \\
\text { preneurship - entrepreneurial management. Strategic Man- } \\
\text { agement Journal, } 11: 17-27 \mathrm{sp} \text {. iss. si sum. }\end{array}$ \\
\hline 45 & 67 & $\begin{array}{l}\text { Cooper, R.G. \& Kleinschmidt, E.J. 1995. Benchmarking } \\
\text { the firms critical success factors in new product development. } \\
\text { Journal of Product Innovation Management, } 12 \text { (5): } 374-391 \\
\text { nov. }\end{array}$ \\
\hline 46 & 66 & $\begin{array}{l}\text { Kalleberg, A.L. \& Leicht, K.T. 1991. Gender and organiza- } \\
\text { tional performance - determinants of small business survival } \\
\text { and success. Academy of Management Journal, } 34 \text { (1): 136- } \\
161 \text { mar. }\end{array}$ \\
\hline 47 & 66 & $\begin{array}{l}\text { Straub, D., Limayem, M., \& Karahannaevaristo, E. } 1995 . \\
\text { Measuring system usage - implications for is theory testing. } \\
\text { Management Science, } 41 \text { (8): 1328-1342 aug. }\end{array}$ \\
\hline 48 & 64 & $\begin{array}{l}\text { Baumol, W.J. 1968. Entrepreneurship in economic theory. } \\
\text { American Economic Review, } 58 \text { (2): } 64-71 \text {. }\end{array}$ \\
\hline 49 & 64 & $\begin{array}{l}\text { Rao, C.H.H. 1971. Uncertainty, entrepreneurship, and } \\
\text { sharecropping in india. Journal of Political Economy, } 79 \text { (3): } \\
\text { 578-595. }\end{array}$ \\
\hline 50 & 63 & $\begin{array}{l}\text { Black, B.S. \& Gilson, R.J. } 1998 \text {. Venture capital and the } \\
\text { structure of capital markets: banks versus stock markets. } \\
\text { Journal of Financial Economics, } 47 \text { (3): } 243-277 \text { Mar. }\end{array}$ \\
\hline
\end{tabular}

The disparity in the amount of citations received by the articles in tables 1 and 2 clearly reflects the greater exposure time enjoyed by the articles from the second period. The time lapse between the appearance of an article and the receipt of citations is also relevant, especially if only citations in ISI journals are included in the count, where time scales for revision, acceptance and publication tend to be extensive. However, as a reflection of these differences, we decided to focus our attention on the more recent articles. 
Table 2. 25 Most frequently cited articles from the period 2000-2005 from the SSCI database

\begin{tabular}{|c|c|c|}
\hline Order & Citations & Articles published between 2000 and 2005 \\
\hline 1 & 122 & $\begin{array}{l}\text { Shane, S.A. \& Venkataraman, S. } 2000 \text {. The promise of } \\
\text { entrepreneurship as a field of research. Academy of Man- } \\
\text { agement Review, } 25 \text { (1): } 217-226 \text { jan. }\end{array}$ \\
\hline 2 & 52 & $\begin{array}{l}\text { Shane, S.A. } 2000 \text {. Prior knowledge and the discovery of } \\
\text { entrepreneurial opportunities. Organization Science, } 11 \text { (4): } \\
448-469 \text { jul-aug. }\end{array}$ \\
\hline 3 & 45 & $\begin{array}{l}\text { Amit R. \& Zott, C. 2001. Value creation in e-business. } \\
\text { Strategic Management Journal, } 22 \text { (6-7): } 493-520 \text { jun-jul. }\end{array}$ \\
\hline 4 & 45 & $\begin{array}{l}\text { Autio, E., Sapienza, H.J. \& Almeida, J.G. } 2000 \text {. Effects of } \\
\text { age at entry, knowledge intensity, and imitability on interna- } \\
\text { tional growth. Academy of Management Journal, } 43 \text { (5): 909- } \\
924 \text { oct. }\end{array}$ \\
\hline 5 & 36 & $\begin{array}{l}\text { Heaton, J. \& Lucas, D. } 2000 \text {. Portfolio choice and asset } \\
\text { prices: the importance of entrepreneurial risk. Journal of Fi- } \\
\text { nance, } 55 \text { (3): } 1163-1198 \text { jun. }\end{array}$ \\
\hline 6 & 30 & $\begin{array}{l}\text { Hamilton, B.H. } 2000 \text {. Does entrepreneurship pay? an } \\
\text { empirical analysis of the returns to self-employment. Journal } \\
\text { of Political Economy, } 108 \text { (3): } 604-631 \text { jun. }\end{array}$ \\
\hline 7 & 29 & $\begin{array}{l}\text { McDougall, P.P. \& Oviatt, B.M. } 2000 \text {. International entre- } \\
\text { preneurship: the intersection of two research paths. Acad- } \\
\text { emy of Management Journal, } 43 \text { (5): } 902-906 \text { oct. }\end{array}$ \\
\hline 8 & 27 & $\begin{array}{l}\text { Guillen, M.F. } 2000 \text {. Business groups in emerging econo- } \\
\text { mies: a resource-based view. Academy of Management } \\
\text { Journal, } 43 \text { (3): } 362-380 \text { jun. }\end{array}$ \\
\hline 9 & 26 & $\begin{array}{l}\text { Petersen, M.A. \& Rajan, R.G. } 2002 \text {. Does distance still } \\
\text { matter? the information revolution in small business lending. } \\
\text { Journal of Finance, } 57 \text { (6): } 2533-2570 \text { dec. }\end{array}$ \\
\hline 10 & 26 & $\begin{array}{l}\text { Miner, A.S., Bassoff, P. \& Moorman, C. 2001. Organiza- } \\
\text { tional improvisation and learning: a field study. Administra- } \\
\text { tive Science Quarterly, } 46 \text { (2): } 304-337 \text { jun. }\end{array}$ \\
\hline 11 & 26 & $\begin{array}{l}\text { Chandy, R.K. \& Tellis, G.J. } 2000 \text {. The incumbent's curse? } \\
\text { incumbency, size, and radical product innovation. Journal of } \\
\text { Marketing, } 64 \text { (3): 1-17 jul. }\end{array}$ \\
\hline 12 & 23 & $\begin{array}{l}\text { Lu, J.W. \& Beamish, P.W. 2001. The internationalization } \\
\text { and performance of smes. Strategic Management Journal, } \\
22 \text { (6-7): } 565-586 \text { jun-jul. }\end{array}$ \\
\hline 13 & 23 & $\begin{array}{l}\text { Stein, J.C. 2002. Information production and capital allo- } \\
\text { cation: decentralized versus hierarchical firms. Journal of Fi- } \\
\text { nance, } 57 \text { (5): 1891-1921 oct. }\end{array}$ \\
\hline 14 & 22 & $\begin{array}{l}\text { Ahuja, G. \& Lampert, C.M. 2001. Entrepreneurship in the } \\
\text { large corporation: a longitudinal study of how established } \\
\text { firms create breakthrough inventions. Strategic Management } \\
\text { Journal, } 22 \text { (6-7): } 521-543 \text { jun-jul. }\end{array}$ \\
\hline 15 & 21 & $\begin{array}{l}\text { Wallsten, S.J. 2000. The effects of government-industry } \\
\text { r\&d programs on private r\&d: the case of the small business } \\
\text { innovation research program. Rand Journal of Economics, } \\
31 \text { (1): } 82-100 \text { spr. }\end{array}$ \\
\hline 16 & 21 & $\begin{array}{l}\text { Etzkowitz, H., Webster A., Gebhardt C., et al. 2000. The } \\
\text { future of the university and the university of the future: evolu- } \\
\text { tion of ivory tower to entrepreneurial paradigm. Research } \\
\text { Policy, } 29 \text { (2): } 313-330 \text { feb. }\end{array}$ \\
\hline 17 & 21 & Simon, M., Houghton, S.M. \& Aquino, K. 2000. Cognitive, \\
\hline
\end{tabular}




\begin{tabular}{|c|c|c|}
\hline & & $\begin{array}{l}\text { biases, risk perception and venture formation: how individu- } \\
\text { als decide to start companies. Journal of Business Ventur- } \\
\text { ing, } 15 \text { (2): } 113-134 \text { mar. }\end{array}$ \\
\hline 18 & 20 & $\begin{array}{l}\text { Friedman, E., Johnson, S., Kaufmann. D., et al. } 2000 \text {. } \\
\text { Dodging the grabbing hand: the determinants of unofficial } \\
\text { activity in } 69 \text { countries. Journal of Public Economics, } 76 \text { (3): } \\
459-493 \text { jun. }\end{array}$ \\
\hline 19 & 20 & $\begin{array}{l}\text { Casper, S. 2000. Institutional adaptiveness, technology } \\
\text { policy, and the diffusion of new business models: the case of } \\
\text { german biotechnology. Organization Studies, } 21 \text { (5): } 887- \\
914 \text {. }\end{array}$ \\
\hline 20 & 20 & $\begin{array}{l}\text { Hult, G.T.M. \& Ketchen, D.J. 2001. Does market orienta- } \\
\text { tion matter?: a test of the relationship between positional ad- } \\
\text { vantage and performance. Strategic Management Journal, } \\
22 \text { (9): 899-906 sep. }\end{array}$ \\
\hline 21 & 20 & $\begin{array}{l}\text { Shane, S.A. \& Cable, D.M. 2002. Network ties, reputa- } \\
\text { tion, and the financing of new ventures. Management Sci- } \\
\text { ence, } 48 \text { (3): } 364-381 \text { mar. }\end{array}$ \\
\hline 22 & 19 & $\begin{array}{l}\text { Johnson, S., McMillan, J. \& Woodruff, C. 2002. Courts } \\
\text { and relational contracts. Journal of Law Economics \& Or- } \\
\text { ganization, } 18 \text { (1): } 221-277 \text { apr. }\end{array}$ \\
\hline 23 & 19 & $\begin{array}{l}\text { Rothaermel, F.T. 2001. Incumbent's advantage through } \\
\text { exploiting complementary assets via interfirm cooperation. } \\
\text { Strategic Management Journal, } 22 \text { (6-7): } 687-699 \text { jun-jul. }\end{array}$ \\
\hline 24 & 19 & $\begin{array}{l}\text { Thursby, J.G. \& Thursby, M.C. } 2002 \text {. Who is selling the } \\
\text { ivory tower? sources of growth in university licensing. Man- } \\
\text { agement Science, } 48 \text { (1): } 90-104 \text { jan. }\end{array}$ \\
\hline 25 & 19 & $\begin{array}{l}\text { Berger, A.N., Klapper, L.F. \& Udell, G.F. } 2001 \text {. The ability } \\
\text { of banks to lend to informationally opaque small businesses. } \\
\text { Journal of Banking \& Finance, } 25 \text { (12): } 2127-2167 \text { dec. }\end{array}$ \\
\hline
\end{tabular}

In the following tables, we will see the citations, received by any type of document, out of the 61,336 quoted by the articles from our initial sample. In practice, this methodology incorporates published articles in journals that are not included in the ISI databases and also includes books and reference material. In fact, 27 of the 50 most frequently cited documents are indeed books, and articles published in journals that do not appear in the ISI can also be found, despite the fact that the initial sample is made up of ISI articles

Table 3 very clearly shows the origin of the theoretical antecedents of the field of entrepreneurship.

Table 3. 50 Most frequently cited documents in the 200 most frequently cited articles in the SSCI

\begin{tabular}{l|l|c|}
\cline { 2 - 3 } Order & \multicolumn{1}{|c|}{ Document } & Citations \\
\cline { 2 - 4 } 1 & $\begin{array}{l}\text { Schumpeter, J.A. 1934. The theory of economic develop- } \\
\text { ment: an inquiry into profits, capital, credit, interest, and the } \\
\text { business cycle. Harvard University Press, Cambridge, MA. }\end{array}$ & 31 \\
\hline $\begin{array}{l}\text { Porter, M.E. 1980 Competitive Strategy. The Free Press, } \\
\text { New York. }\end{array}$ & 25 \\
\hline $\begin{array}{l}\text { McClelland, D.C. 1961 The Achieving Society. The Free } \\
\text { Press, New York. }\end{array}$ & 22 \\
\hline
\end{tabular}




\begin{tabular}{|c|c|c|}
\hline 4 & $\begin{array}{l}\text { Penrose, E.T. 1959. The Theory of growth of the firm. John } \\
\text { Wiley and Sons, New York. }\end{array}$ & 17 \\
\hline 5 & $\begin{array}{l}\text { Miller, D. 1983. The correlates of entrepreneurship in } 3 \text { types } \\
\text { of firms. Management Science, } 29 \text { (7): } 770-791 .\end{array}$ & 17 \\
\hline 6 & $\begin{array}{l}\text { Vesper, K.H. 1990. New venture strategies. Prentice-Hall, } \\
\text { Englewood Cliffs, NJ. }\end{array}$ & 17 \\
\hline 7 & $\begin{array}{l}\text { Williamson, O.E. } 1975 \text { Markets and Hierarchies: Analysis } \\
\text { and Antitrust Implications. The Free Press, New York. }\end{array}$ & 15 \\
\hline 8 & $\begin{array}{l}\text { Schumpeter, J.A. 1942. Capitalism, Socialism, and Democ- } \\
\text { racy. Harper, New York. }\end{array}$ & 15 \\
\hline 9 & $\begin{array}{l}\text { Nunnally, J.C. 1978. Psychometric Theory. McGraw-Hill, } \\
\text { New York. }\end{array}$ & 15 \\
\hline 10 & $\begin{array}{l}\text { Kirzner, I.M. 1973. Competition and Entrepreneurship. Uni- } \\
\text { versity of Chicago Press, Chicago. }\end{array}$ & 15 \\
\hline 11 & $\begin{array}{l}\text { Lawrence, P.R. \& Lorsch, J. 1967. Organization and Envi- } \\
\text { ronment: Managing Differentiation and Integration. Irwin, } \\
\text { Homewood, IL. }\end{array}$ & 15 \\
\hline 12 & $\begin{array}{l}\text { Brockhaus, R.H. 1982. The Psycology of the entrepreneur, } \\
\text { in Sexton \& Smilor \& Vesper "The Encyclopedia of Entrepre- } \\
\text { neurship" Prentice Hall, Englewood Cliffs, NJ. }\end{array}$ & 14 \\
\hline 13 & $\begin{array}{l}\text { Peters, T.J. \& Waterman, R.H. 1982. In Search of Excel- } \\
\text { lence. Harper \& Row, New York. }\end{array}$ & 13 \\
\hline 14 & $\begin{array}{l}\text { Weick, K.E. 1969. The Social Psycology of Organizing. Ad- } \\
\text { dison-Wesley, Reading, Mass. }\end{array}$ & 13 \\
\hline 15 & $\begin{array}{l}\text { Burgelman, R.A. 1983. A Process Model of Internal Corpo- } \\
\text { rate Venturing in the Diversified Major Firm. Administrative Sci- } \\
\text { ence Quarterly, } 28 \text { ( 2): 223-244. }\end{array}$ & 13 \\
\hline 16 & $\begin{array}{l}\text { Begley, T.M. \& Boyd, D.P. 1987. Psychological characteris- } \\
\text { tics associated with performance in entrepreneurial firms and } \\
\text { smaller businesses. Journal of Business Venturing, } 2 \text { (1): } 79-93 \text {. }\end{array}$ & 13 \\
\hline 17 & $\begin{array}{l}\text { Low, M.B.\& MacMillan, I.C. 1988. Entrepreneurship: Past re- } \\
\text { search and future challenges. Journal of Management, } 14 \text { (2): } \\
\text { 139-161. }\end{array}$ & 13 \\
\hline 18 & $\begin{array}{l}\text { Stinchcombe, A.L. 1965. Social Structure and Organizations. } \\
\text { In: J.G. March (ed) "Handbook of Organizations" }\end{array}$ & 13 \\
\hline 19 & $\begin{array}{l}\text { Chandler, A.D. 1962. Strategy and Structure: Chapters in } \\
\text { the History of the Industrial Enterprise. MIT Press, Cambridge, } \\
\text { Mass. }\end{array}$ & 13 \\
\hline 20 & $\begin{array}{l}\text { Collins, O.F. \& Moore, D.G. 1964. The Enterprising Man. } \\
\text { Michigan State University Press, Michigan. }\end{array}$ & 13 \\
\hline 21 & $\begin{array}{l}\text { Rubin, P.H. 1978. The Theory of the Firm and the Structure } \\
\text { of the Franchise Contract. Journal of Law and Economics, } \\
\text { 21(1): } 223-233 \text {. }\end{array}$ & 13 \\
\hline 22 & $\begin{array}{l}\text { Hannan, M. T. \& J. H. Freeman. 1984. Structural inertia and } \\
\text { organizational change. American Sociological Review } \\
\text { 49(2):149-64. }\end{array}$ & 12 \\
\hline 23 & $\begin{array}{l}\text { Nelson, R. \& Winter, S. 1982. An Evolutionary Theory of } \\
\text { Economic Change. Harvard University Press, Cambridge, MA. }\end{array}$ & 12 \\
\hline 24 & $\begin{array}{l}\text { Cyert, R.M. \& March, J.G. } 1963 \text { A Behavioral Theory of the } \\
\text { Firm. Prentice Hall, Englewood Cliffs, NJ. }\end{array}$ & 12 \\
\hline 25 & $\begin{array}{l}\text { Covin. J.G. \& Slevin, D.P. 1989. Strategic Management of } \\
\text { Small Firms in Hostile and Benign Environments. Strategic } \\
\text { Management Journal, 10(1): } 75-87 \text {. }\end{array}$ & 12 \\
\hline 26 & $\begin{array}{l}\text { Mathewson, G.F. \& Winter, R.A. 1985. The Economics of } \\
\text { Franchise Contracts Journal of Law and Economics, 28(3): 503- } \\
526 .\end{array}$ & 12 \\
\hline
\end{tabular}


Drucker, P. 1985. Innovation and entrepreneurship: practice and principles. Heinemann, London.

Sandberg, W.R. \& Hofer, C.W. 1987. Improving new venture performance - the role of strategy, industry structure, and the entrepreneur. Journal of Business Venturing, 2 (1): 5-28.

Kanter, R. M. 1983. The Change Masters: Corporate Entrepreneurs at Work. Simon \& Schuster, New York.

Mintzberg, H. 1979. Structuring of organizations: a synthesis of the research. Prentice Hall, Englewood Cliffs, NJ.

Miller, D. \& Friesen, P.H. 1982. Innovation in Conservative and Entrepreneurial Firms - 2 Models of Strategic Momentum. Strategic Management Journal, 3 (1): 1-25.

Hornaday, J.A. \& Aboud, J. 1971. Characteristics of Successful Entrepreneurs. Personnel Psycology, 24(2): 141-153.

Knight, F.H. 1921. Risk, Uncertainty and Profit. Hougthon Mifflin, New York.

Diamond, D. 1984. Financial intermediation and delegated monitoring, Review of Economic Studies, 51, 393-414.

Burgelman, R.A. 1983. Corporate entrepreneurship and strategic management - insights from a process study. Management Science, 29 (12): 1349-1364.

Williamson, O.E. 1985. The Economic Institutions of Capitalism. The Free Press, New York. Pfeffer, J. \&; Salancik, G.R. 1978. The External Control of Organizations: A Resource Dependence Perspective. Harper and Row, New York.

(1)
York. Pinchot, G. 1985. Intrapreneuring. Harper and Row, New

Evans, D. \& Leighton, L. 1989. Some empirical aspects of entrepreneurship. American Economic Review. 79(3): 519-535. Porter, M.E. 1985. Competitive Advantage. The Free Press, New York.

Hannan, M.T. \& Freeman, J. 1977. The Population Ecology of Organizations. American Journal of Sociology, 82: 929,964. Smith, N.R. 1967. The Entrepreneur and his Firm. Michigan State University Press, Michigan.

Caves, R.E. \& Murphy, W.F. 1976. Franchising - firms, markets, and intangible assets. Southern Economic Journal, 42 (4): 572-586.

Child, J. 1972. Organization Structure, Environment. and Performance: The Role of Strategic Choice, Sociology, 6: 1-22. Aldrich, H.E. \& Zimmer, C. 1986. Entrepreneurship through Social Networks. in Sexton D.; Smilor, R.W.(eds) The Art and Science of Entrepreneurship. Ballinger, New York. Brickley, J.A. \& Dark, F.H. 1987. The choice of organizational form - the case of franchising. Journal of Financial Economics, 18 (2): 401-420.

MacMillan,I.C. \& Day,D. 1987.Corporate ventures into industrial markets: Dynamics of aggressive entry. Journal of Business Venturing, 2(1): 29-39.

Guth, W.D. \& Ginsberg, A. 1990. Guest Editors' Introduction: Corporate Entrepreneurship. Strategic Management Journal, 11(5): 5-15

Burns, L.R. \& Stalker, G.M.1961. The Management of Innovation. Oxford University Press, Oxford

Stiglitz, JE, \& Weiss,A. 1981. Credit rationing in markets with 
imperfect information, American Economic Review, 71: 393-

410.

Tabla 4. 25 Most frequently cited documents in the 100 most frequently cited ISI (2000-2005) articles in the SSCI

\begin{tabular}{|c|c|c|}
\hline Order & Document & Citations \\
\hline 1 & $\begin{array}{l}\text { Schumpeter, J.A. 1934. The theory of economic develop- } \\
\text { ment: an inquiry into profits, capital, credit, interest, and the } \\
\text { business cycle. Harvard University Press, Cambridge, MA. }\end{array}$ & 19 \\
\hline 2 & $\begin{array}{l}\text { Barney, J.B. 1991. Firm resources and sustained competi- } \\
\text { tive advantage. Journal of Management, 17(1): } 99-120 \text {. }\end{array}$ & 16 \\
\hline 3 & $\begin{array}{l}\text { Venkataraman, S. 1997. The distinctive domain of entrepre- } \\
\text { neurship research: An editor's perspective, en: Katz, J. \& } \\
\text { Brockhaus (eds) "Advances in entrepreneurship, firm emer- } \\
\text { gence, and growth, Vol. 3, p. 119-138, Greenwich, CT: JAI } \\
\text { Press. }\end{array}$ & 12 \\
\hline 4 & $\begin{array}{l}\text { Schumpeter, J.A. 1942. Capitalism, Socialism, and Democ- } \\
\text { racy. Harper, New York. }\end{array}$ & 11 \\
\hline 5 & $\begin{array}{l}\text { Burt, R.S. 1992. Structural Holes: The Social Structure of } \\
\text { Competition. Harvard University Press, Cambridge, MA. }\end{array}$ & 11 \\
\hline 6 & $\begin{array}{l}\text { Busenitz, L.W. \& Barney, J.B. 1997. Differences between } \\
\text { entrepreneurs and managers in large organizations: Biases and } \\
\text { heuristics in strategic decision-making. Journal of Business } \\
\text { Venturing, 12(1): 9-30. }\end{array}$ & 10 \\
\hline 7 & $\begin{array}{l}\text { Nelson, R. \& Winter, S. 1982. An Evolutionary Theory of } \\
\text { Economic Change. Harvard University Press, Cambridge, MA. }\end{array}$ & 10 \\
\hline 8 & $\begin{array}{l}\text { Stinchcombe, A.L. 1965. Social Structure and Organizations. } \\
\text { In: J.G. March (ed) "Handbook of Organizations" }\end{array}$ & 10 \\
\hline 9 & $\begin{array}{l}\text { Shane, S.A. \& Venkataraman, S. } 2000 \text {. The promise of en- } \\
\text { trepreneurship as a field of research. Academy of Management } \\
\text { Review, } 25(1): 217-226 \text {. }\end{array}$ & 10 \\
\hline 10 & $\begin{array}{l}\text { Gompers, P.A. \& Lerner, J. 1999. The Venture Capital Cy- } \\
\text { cle. MIT Press, Cambridge. }\end{array}$ & 10 \\
\hline 11 & $\begin{array}{l}\text { Lumpkin, GT, \& Dess, GG 1996. Clarifying the entrepreneu- } \\
\text { rial orientation construct and linking it to performance. Academy } \\
\text { of Management Review, 21(1): 135-172. }\end{array}$ & 10 \\
\hline 12 & $\begin{array}{l}\text { Aldrich, H.E. \& Zimmer, C. 1986. Entrepreneurship through } \\
\text { Social Networks. in Sexton D.; Smilor, R.W.(eds) The Art and } \\
\text { Science of Entrepreneurship. Ballinger, New York. }\end{array}$ & 9 \\
\hline 13 & $\begin{array}{l}\text { Evans, D. \& Leighton, L. 1989. Some empirical aspects of } \\
\text { entrepreneurship. American Economic Review. 79(3): 519-535. }\end{array}$ & 9 \\
\hline 14 & $\begin{array}{l}\text { Low, M.B.\& MacMillan, I.C. 1988. Entrepreneurship: Past re- } \\
\text { search and future challenges. Journal of Management, } 14 \text { (2): } \\
\text { 139-161. }\end{array}$ & 9 \\
\hline 15 & $\begin{array}{l}\text { Gartner, W.B. 1988. Who is an entrepreneur? Is the Wrong } \\
\text { Question . American Journal of Small Business, 12(4): 11-22 }\end{array}$ & 9 \\
\hline 16 & $\begin{array}{l}\text { Aldrich, H.E. 1999. Organizations evolving. Sage, Thousand } \\
\text { Oaks, CA. }\end{array}$ & 9 \\
\hline 17 & $\begin{array}{l}\text { Shaver, K.G. \& Scott, L.R. 1991. Person, process, choice: } \\
\text { the psychology of new venture creation. Entrepreneurship The- } \\
\text { ory and Practice, } 16(2): 23-45 \text {. }\end{array}$ & 8 \\
\hline 18 & Kirzner, I.M. 1973. Competition and Entrepreneurship. Uni- & 8 \\
\hline
\end{tabular}




\begin{tabular}{|c|c|c|}
\hline & versity of Chicago Press, Chicago & \\
\hline 19 & $\begin{array}{l}\text { Petersen, M.A. \& Rajan, R.G. } 1994 \text {. The benefits of lending } \\
\text { relationships - evidence from small business data. Journal of } \\
\text { Finance, } 49 \text { (1): 3-37. }\end{array}$ & 8 \\
\hline 20 & $\begin{array}{l}\text { Zucker, L.G., Darby M.R. \& Brewer M.B. 1998. Intellectual } \\
\text { Human Capital and the Birth of US Biotechnology Enterprises. } \\
\text { American Economic Review 88(1): } 290-306 \text {. }\end{array}$ & 8 \\
\hline 21 & $\begin{array}{l}\text { Cohen, W.M. \& Levinthal, D.A. 1990. Absorptive-Capacity - } \\
\text { A New Perspective on Learning and Innovation. Administrative } \\
\text { Science Quarterly, 35(1): 128-152. }\end{array}$ & 7 \\
\hline 22 & $\begin{array}{l}\text { Arrow, K. J. 1962. "Economic Welfare and the Allocation of } \\
\text { Resources for Invention." In The Rate and Direction of Inventive } \\
\text { Activity: Economic and Social Factors, National Bureau of Eco- } \\
\text { nomic Research. Princeton University Press, Princeton. }\end{array}$ & 7 \\
\hline 23 & $\begin{array}{l}\text { Jaffe, A.; Trajtenberg, M. \& Henderson, R. 1993. Geographic } \\
\text { localization of knowledge spillovers as evidence by patent cita- } \\
\text { tions. Quaterley Journal of Economics, 108(3): } 577-598 \text {. }\end{array}$ & 7 \\
\hline 2 & $\begin{array}{l}\text { Penrose, E.T. 1959. The Theory of growth of the firm. John } \\
\text { Wiley and Sons, New York. }\end{array}$ & 7 \\
\hline 25 & $\begin{array}{l}\text { Petersen, M.A. \& Rajan, R.G. } 1995 \text {. The Effect of Credit } \\
\text { Market Competition On Lending Relationships. Quarterly Jour- } \\
\text { nal of Economics, } 110 \text { (2): } 407-443 \text {. }\end{array}$ & 7 \\
\hline
\end{tabular}

Table 4 shows the evolution of the underlying arguments that lend weight to research and thus to new theories on entrepreneurship. Despite maintaining a nucleus of references that are of a more stable nature than one would expect, they substitute, slowly but surely, the psychological analysis of individuals for, on the one hand, a focus on groups and teams, and on the other moves towards placing attention on opportunities as an economic cause and effect of disequilibrium and on income for businesses. A methodological change can also be described, along with the attempt to develop a theoretical basis for the study of the business function.

\section{References}

Acs, Z.J. \& Audretsch, D.B. (1990). Innovation and Small Firms. Cambridge, MA: MIT Press.

Alvarez, S.A. \& Busenitz, L.W. (2001). The entrepreneurship of resource-based theory. Journal of Management, 27, 755-775.

Audretsch, D.B., Castrogiovanni, G.J., Ribeiro, D., \& Roig, S. (2005). Linking entrepreneurship and management: Welcome to the International Entrepreneurship and Management Journal. International Entrepreneurship and Management Journal, 1, 5-7.

Barringer, B.R. \& Bluedorn, A.C. (1999). The relationship between corporate entrepreneurship and strategic management. Strategic Management Journal, 20, 421-444.

Brown, T.E., Davidsson, P. \& Wiklund, J. (2001). An operationalization of Stevenson's conceptualization of entrepreneurship as opportunity-based firm behaviour. Strategic Management Journal, 22, 953-968. 
Bruyat, C., \& Julien, P-A. (2000). Defining the field of research in entrepreneurship. Journal of Business Venturing, 16, 165-180.

Busenitz, L.W., West III, G.P., Shepherd, D., Nelson, T., Chandler, G.N., \& Zacharakis, A. (2003). Entrepreneurship research in emergence: Past trends and future directions. Journal of Management, 29, 285-308.

Coviello, N.E. \& Jones, M.V. (2004). Methodological sigues in international entrepreneurship research. Journal of Business Venturing, 19, 485-508.

Eckhardt, J.T. \& Shane, S.A. (2003). Opportunities and entrepreneurship. Journal of Management, 29, 333-349.

Fiet, J.O. (2001). The pedagogical side of entrepreneurship theory. Journal of Business Venturing, 16, 101-117.

Finkle, T.A., Kuratko, D.F. \& Goldsby, M.G. (2006). An examination of entrepreneurship centers in the United States: A national survey. Journal of Small Business Management, 44, 184-206.

Hitt, M.A., Ireland, R.D., Camp, S.M., \& Sexton, D.L. (2001). Guest editors' introduction to the special issue strategic entrepreneurship: entrepreneurial strategies for wealth creation. Strategic Management Journal, 22, 479-491.

Kihlstrom, R.E. \& Laffont, J.J. (1979). General equilibrium entrepreneurial theory of firm formation based on risk aversion. Journal of Political Economy, 87, 719-748.

Knight, F. (1921) Risk, uncertainty and profit. Boston, MA: Houghton Mifflin.

Lee, S.M. \& Peterson, S.J. (2000). Culture, entrepreneurial orientation, and global competitiveness. Journal of World Business, 35, 401-416.

Leibenstein, H. (1979). Branch of economics is missing - Micro-Micro theory. Journal of Economic Literature, 17, 477-502.

McClelland, D.C. (1961). The achieving society. Princeton, NJ: Van Nostrand.

Miller, D. (1983). The correlates of entrepreneurship in three types of firms. Management Science, 29, 770-791.

Reynolds, P.D. (2005). Understanding business creation: Serendipity and scope in two decades of business creation studies. Small Business Economics, 24, 359-364.

Schumpeter, J.A. (1934). The theory of economic development. Cambridge: Harvard University Press.

Schumpeter, J.A. (1942). Capitalism, socialism and democracy. New York: Harper.

Shane, S.A. \& Venkataraman, S. (2000). The promise of entrepreneurship as a field of research. Academy of Management Review, 25, 217-226.

Stevenson, H.H. \& Jarillo, J.C. (1990). A paradigm of entrepreneurship research: Entrepreneurial management. Strategic Management Journal, 11, 17-27.

Tushman, M.L. \& Anderson, P. (1986). Technological discontinuities and organizational environments. Administrative Science Quarterly, 31, 439-465. 